\title{
Effects of defoliation and competition on total non- structural carbohydrates of spotted knapweed
}

\author{
JOHN R. LACEY, KATHRIN M. OLSON-RUTZ, MARSHALL R. HAFERKAMP AND \\ GREGORY A. KENNETT
}

\begin{abstract}
Authors are extension range management specialist, and research associate, Animal and Range Sciences Department, Montana State University, Bozeman; range scientist, USDA/ARS Ft. Keogh Livestock Range Research Station, Miles City; and land resource consultant, Missoula, Mont., respectively.
\end{abstract}

\begin{abstract}
Spotted knapweed (Centaurea maculosa Lam.) is replacing native bunchgrasses and interfering with resource management objectives on many ranges in the northern Intermountain Region. Herbicides, biological control agents, and fire have not successfully contained spotted knapweed. Since knapweed is grazed in some situations, effects of defoliation and competition on total nonstructural carbohydrates (TNC) of spotted knapweed plants were determined in this study. Transplanted knapweed plants were grown for 6 months in a greenhouse under 3 levels of competition with bluebunch wheatgrass (Pseudoroegneria spicata [Pursh] Love) and 3 levels of defoliation. Total nonstructural carbohydrates (pool and concentration) were determined at the end of the experiment. Concentration and pools of carbohydrates generally varied among stems, roots, crowns, and with monthly defoliations. Importance of stems for carbohydrate storage was more evident in analyses of pools rather than concentrations. Monthly defoliations decreased carbohydrate concentrations by about $50 \%$, and pools by about $80 \%$ respectively within stems, roots, and crowns. While competition from bluebunch wheatgrass influenced total nonstructural carbohydrates concentrations, it did not influence pools. Although frequent defoliations of spotted knapweed reduced carbohydrates, other factors probably limit the feasibility of using grazing animals to control spotted knapweed on native bunchgrass ranges in western North America.
\end{abstract}

Keywords: Centaurea maculosa Lam., Pseudoroegneria spicata (Pursh) Love, carbohydrate reserves, environmental stress, greenhouse, noxious range weed

Spotted knapweed (Centaurea maculosa Lam.) was introduced into the Pacific Northwest from Eurasia around 1900 (Roché and Talbott 1986). It is an aggressive invader of range and pasture in the northern Intermountain Region (Tyser and Key 1988, Lacey et al.

Research was funded in part by Montana Noxious Weed Trust Grant. The authors appreciate the Natural Resource Laboratory at Colorado State University and the USDAARS Forage and Range Research Laburatory at Lugan, Ut for their assistance in deretmining carbohydrate content. Mention of a product or instrument in this paper does not constitute a recommendation by the USDA or Montana State University.

Manuscript 22 Feb. 1994.
1992). In Montana, spotted knapweed has adversely impacted the structure and function of 1.9 million hectares of range and pastureland (Lacey and Olson 1991, Bedunah 1992). Successful control of spotted knapweed may require the integrated use of chemicals, biological organisms and cultural methods (Roché et al. 1986).

Watson and Renney (1974) reported that animals seldom grazed spotted knapweed. However, the plant has nutritional value (Kelsey and Mihalovich 1987) and some livestock producers (Robbins 1990) report that livestock graze knapweed. Most knapweed-infested range and pasture land is grazed, and above- and belowground biomass of knapweed, are adversely impacted by defoliation (Kennett et al. 1992). However, the response of carbohydrate reserves to defoliation and competition was not evaluated.

Herbaceous perennial plants accumulate soluble carbohydrate reserves or nonstructural carbohydrates (TNC) (Menke and Trlica 1981) for regrowth or as a buffer when photosynthesis is not able to supply energy for plant functions (Caldwell 1984). Concentrations of these compounds in various plant parts change with plant vigor, defoliation, and with other environmental factors (Donart and Cook 1970, Reynolds 1971, Menke and Trlica 1981, Lym and Messersmith 1987, and Boyce and Volenec 1992). However, the total soluble carbohydrate quantity or "pools" (biomass $x$ concentration) available in the plant, rather than concentration alone, probably provide a more useful assessment of plant vigor (Caldwell et al. 1981, Caldwell 1984, Richards and Caldwell 1985). TNC concentrations have been used to develop principles for alfalfa (Medicago sativa L.) production (Reynolds 1971, Boyce and Volenec 1992), weed control (Lym and Messersmith 1987) and range management (Donart and Cook 1970, Menke and Trlica 1981) and pools have been recommended for use in understanding the growth of bluebunch wheatgrass [Pseudoroegneria spicata (Pursh) Löve] and crested wheatgrass (Agropyron cristatum (L.) Gaert.) (Richards and Caldwell 1985).

In this study we determined the effects of defoliation and competition on carbohydrate reserves (pools and concentrations) of spotted knapweed growing in a greenhouse. A better understanding may enhance the development of new weed control strategies for this species.

\section{Methods and Materials}

Spotted knapweed response to a combination of competition (interand intra-specific), defoliation, and light treatments was quantified in a greenhouse at Montana State University. In order to reduce varia- 
tion among plants, 405 mature spotted knapweed and 405 mature bluebunch wheatgrass plants, in the rosette and vegetative stage of growth, respectively, were excavated (to a depth of $10 \mathrm{~cm}$ ) from loam soils (fine-loamy, mixed frigid, typic Ustochrepts and loamyskeletal, mixed Aridic Haploborolls) near Garrison, Montana (46 $32^{\circ}$ Lat). Plants were excavated in May and combinations of 6 plants/pot were immediately planted into 135,19 -liter pots $(28-\mathrm{cm}$ deep and $29-\mathrm{cm}$ wide) containing a pasteurized potting mixture. Seed staks from the previous year's growth were clipped and removed from the plants. Less than $2 \%$ of the plants died during transplanting. These plants were immediately replaced with stock from the original excavation. Defoliation treatments were initiated in June and terminated at the end of October.

\section{Competition Treatments}

Three competition treatments were formed by varying intra- and interspecific competition within a pot. The 3 treatments were: (1) intraspecific competition with 6 spolted knapweed and 0 bluebunch wheatgrass plants/pot; (2) interspecific competition with 4 spotted knapweed and 2 bluebunch wheatgrass plants/pot; and (3) interspecific competition with 2 spotted knapweed and 4 bluebunch wheatgrass plants/pot. For the remainder of this paper the 3 treatments will be referred to as $6: 0,4: 2$, and $2: 4$, respectively for treatments 1,2 , and 3 .

\section{Defoliation Treatments}

Three defoliation treatments, varying in frequency and severity, were applied at specific stages of growth: 1) control or no defoliation, 2) a single defoliation removing about $75 \%$ and $50 \%$, respectively of the above-ground weight of knapweed plants (bolt stage) and of wheatgrass (vegetative stage); and 3) multi-defoliations where knapweed and wheatgrass plants were clipped at monthly intervals. Because of variation among individual plants, knapweed plants were defoliated cither in the bolt or flowering stages, while wheatgrass plants were defoliated during the vegetative stage. About $50 \%$ of the above-ground biomass was removed from knapweed plants, and wheatgrass plants were defoliated to a $5-\mathrm{cm}$ height at each of the 4 defoliations. Each competition by defoliation treatment was replicated 5 times.

\section{Light Treatments}

Each defoliation by competition combination was subjected to 3 levels of light (full, $2 / 3$ full, and $1 / 2$ full sunlight). Because it was impractical to shade each pot individually, the greenhouse was subdivided into 3 parts, with each part receiving a distinct level of light. The full light treatment was represented by normal greenhouse conditions. The $2 / 3$ and $1 / 2$ light treatments were created by suspending a single-and double-shade cloth (black mesh screen) $70 \mathrm{~cm}$ above the pots, respectively. A Licor light meter was used to verify that photosynthetic radiation was reduced, compared with full light, by $33 \%$ and $50 \%$ in the $2 / 3$ and $1 / 2$ light treatments, respectively. Length of daylight was not altered. Each pot was rotated 90 degrees and relocated, systematically within its shade cloth constraints, on a weekly basis to minimize the effect of environmental variation within the greenhouse.

An equal amount of water was added to each pot when the plants under full sun began to wilt. Therefore, plants under partial shade had a more moist environment. Greenhouse temperatures were adjusted to simulate diurnal and nocturnal conditions during the May to October growing season.

\section{TNC Determination}

Plant samples for total nonstructural carbohydrates determination were collected at the end of the greenhouse experiment. The pots were tipped on their sides, individual knapweed plants removed, and roots washed. Collections were made between 1300-1500 hours to minimize diurnal variations in nonstructure carbohydrate concentrations and individual knapweed plants were dissected into herbage (stems, leaves, buds, flowers, and seeds), crowns and roots. Crowns included material $12 \mathrm{~mm}$ above and $12 \mathrm{~mm}$ below the soil surface. Plants were placed in a drying oven within 1 hour from the time of excavation to minimize enzymatic hydrolysis of carbohydrate fractions. Herbage, crowns, and roots were oven-dried for $15 \mathrm{~min}$ at $100^{\circ} \mathrm{C}$ then overnight at $65^{\circ} \mathrm{C}$, weighed and ground to pass through a 40 -mesh screen. A sample of the roots was incinerated at $500^{\circ} \mathrm{C}$ to determine ash free weight.

Herbage, crown, and root samples from the 5 replicated pots were combined to form composite samples for subsequent TNC analyses. There was insufficient material for analysis of some 4:2 and 2:4 treatments because there were fewer knapweed plants. Also plants were smaller and some material had previously been examined in an autoanalyzer. Total nonstructural carbohydrates were extracted from a $0.5 \mathrm{~g}$ plant sample with $0.2 \mathrm{~N}$ sulfuric acid (Smith et al. 1964). Aliquots of the extract were then used to determine TNC levels on a glucose equivalent basis (Trlica and Cook 1971).

\section{Statistical Design and Analyses}

The 3 levels of defoliation were combined with 3 levels of competition and randomly arranged within 3 levels of light. Each defoliation hy competition combination was replicated in 5 pots in each level of light. Analysis of variance, pooling across plant part and blocking on light, indicated that light did not significantly affect TNC or TNC pool. Therefore, the 3 light treatments were used as replicates, and 3-way analysis of variance (SAS 1988) was used to measure effects of competition and defoliation on both, percentage TNC and TNC pools for plant parts (roots, crowns and stems). Although there were 81 observations $[$ defoliation $=3$, competition $=$

\section{$\square$ stem $\square$ roots $\square$ crown}

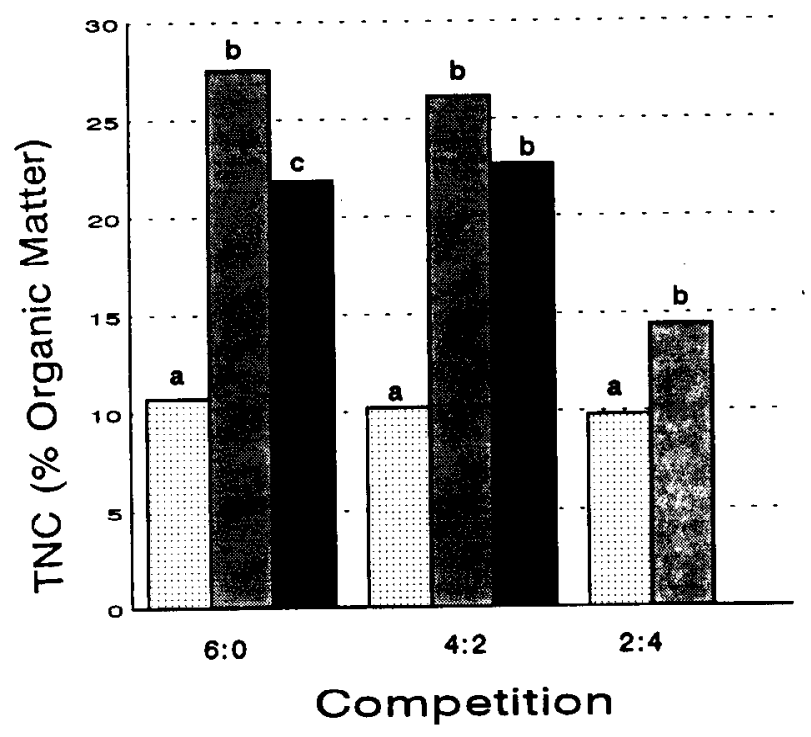

Fig. 1. Spotted knapweed TNC concentration by plant part at 3 levels of competition: 6 spotted knapweed and 0 bluebunch wheatgrass plants (6:0), 4 spotted knapweed and 2 bluebunch wheatgrass plants $(4: 2)$, and 2 spotted knapweed and 4 bluebunch wheatgrass plants (2:4). Means within a competition treatment followed by different letters are significantly different letters are significantly different $(P<0.05)$. 
Table 1. Statistical significance of variations in total nonstructural carbohydrates in spotted knapweed with increasing defoliation and competition, and among plant parts.

\begin{tabular}{llccc}
\hline \hline $\begin{array}{l}\text { Dependent } \\
\text { Variable' }\end{array}$ & $\begin{array}{l}\text { Source of } \\
\text { Variation }^{2}\end{array}$ & DF & Mean Square & Pr.>F \\
\hline \% TNC & Defoliation & 2 & 512.6 & 0.0001 \\
& Competition & 2 & 196.8 & 0.0003 \\
& Plant Part & 2 & 914.8 & 0.0001 \\
& Competition & & & \\
& x Plant Part & 3 & 109.8 & 0.0031 \\
Pooled TNC & Defoliation & 2 & 407.8 & 0.0001 \\
& Competition & 2 & 36.7 & 0.1547 \\
& Plant Part & 2 & 233.9 & 0.0001 \\
& Competition & & & \\
& x Plant Part & 4 & 38.1 & 0.1070
\end{tabular}

TNC is a measure of $\%$ organic matter while Pooled TNC $=\%$ TNC $\times$ Biomass.

${ }^{2}$ Defoliation by competition and defoliation by plant part interactions were not significant.

3 , plant part $=3$, and replication (light) $=3$ ] in the data set, insufficient crown material in the $2: 4$ and $4: 2$ competition classes limited the number of observations to 60 .

Main effect means were separated using Duncan Multiple Range tests when there was a significant treatment effect. Because of an interaction between competition and plant parts, orthogonal contrasts were used to compare total nonstructural carbohydrates concentration of roots, crowns, and stems within each of 3 levels of competition. Comparisons between each of the 9 competition $x$ plant part interactions were made using t-tests, with 2 and $24 \mathrm{df}$ between and within competition, respectively. Tests were considered significant if $P \leq 0.05$. Simple linear regression analyses were used to determine correlation between TNC and TNC pool. Separate analyses were run for roots, crowns, and stems.

\section{Results and Discussion}

\section{Carbohydrate Concentration}

Defoliation affected total nonstructural carbohydrates (TNC) concentrations of spotted knapweed (Table 1). While concentrations were similar in control and plants defoliated oncc, concentrations declined $(P \leq 0.001)$ when plants were clipped monthly (Table 2$)$. Carbohydrate concentrations in stems were generally 2-3 times lower than in crowns and roots.

Analysis of variance revealed a significant competition $x$ plant part interaction (Table 1). This interaction is a result of the $4: 2$ competition treatment showing no difference in \% total nonstructural carbohydrates between roots and crowns, whereas the total nonstructural carbohydrates concentration in roots is greater than for crowns in the 6:0 treatment (Fig. 1). However, the similarity in concentration patterns make it difficult to predict the biological significance of the different TNC concentrations.

\section{Carbohydrate Pool}

Total nonstructural carbohydrates pools of spotted knapweed varied by defoliation treatment and plant part (Table 1). Stem-and rootpools were about 3 times larger than crown-pools in the controls; however, differences in pool size declined $(P \leq 0.01)$ with increasing frequency of defoliation (Table 2). Pool size was expected to be affected by defoliation because biomass at termination of treatments was less for defoliated plants (Kennett et al. 1992). Pools were not significantly affected by competition with bluebunch wheatgrass.
Table 2. Mean total nonstructural carbohydrates on organic matter basis (\%) and TNC pool(g) on organic matter basis of spotted knapweed as influenced by defoliation and competition.'

\begin{tabular}{|c|c|c|c|c|}
\hline \multicolumn{2}{|c|}{ Treatments } & \multirow{2}{*}{$\begin{array}{l}\text { Plant } \\
\text { part }\end{array}$} & \multirow{2}{*}{ TNC } & \multirow{2}{*}{ TNC (Pool) } \\
\hline Defoliation & Competition & & & \\
\hline & & & $(\%)$ & (g) \\
\hline \multirow[t]{3}{*}{ Control } & 6 CEMA;0 PSSP & $\begin{array}{l}\text { Stem } \\
\text { Root } \\
\text { Crown }\end{array}$ & $\begin{array}{l}12.6(1.3) \\
39.7(1.8) \\
26.3(2.2)\end{array}$ & $\begin{array}{r}18.9(1.5) \\
22.8(6.2) \\
6.7(0.3)\end{array}$ \\
\hline & 4 CEMA;2 PSSP & $\begin{array}{l}\text { Stem } \\
\text { Root } \\
\text { Crown }\end{array}$ & $\begin{array}{l}12.2(1.6) \\
27.1(5.9) \\
26.9(0.1)\end{array}$ & $\begin{array}{r}16.1(2.4) \\
19.5(9.9) \\
5.9(0.4)\end{array}$ \\
\hline & 2 CEMA;4 PSSP & $\begin{array}{l}\text { Stem } \\
\text { Root } \\
\text { Crown }\end{array}$ & $\begin{array}{c}12.0(2.3) \\
18.0(6.1) \\
-\end{array}$ & $\begin{array}{c}15.1(2.2) \\
7.6(0.7) \\
-\end{array}$ \\
\hline \multirow[t]{3}{*}{$\begin{array}{l}\text { Clip } \\
\text { (bolt) }\end{array}$} & 6 CEMA;0 PSSP & $\begin{array}{l}\text { Stem } \\
\text { Root } \\
\text { Crown }\end{array}$ & $\begin{array}{l}12.9(1.3) \\
28.7(3.5) \\
25.2(10.0)\end{array}$ & $\begin{array}{r}12.1(2.8) \\
12.5(1.3) \\
5.4(0.7)\end{array}$ \\
\hline & 4 CEMA;2 PSSP & $\begin{array}{l}\text { Stem } \\
\text { Root } \\
\text { Crown }\end{array}$ & $\begin{array}{l}12.0(0.9) \\
28.3(3.7) \\
25.4(2.4)\end{array}$ & $\begin{array}{r}10.2(1.4) \\
16.8(1.4) \\
5.9(0.0)\end{array}$ \\
\hline & 2 CEMA;4 PSSP & $\begin{array}{l}\text { Stem } \\
\text { Root } \\
\text { Crown }\end{array}$ & $\begin{array}{c}10.6(0.8) \\
16.9(2.1) \\
-\end{array}$ & $\begin{array}{c}11.4(1.4) \\
12.2(1.4) \\
-\end{array}$ \\
\hline \multirow[t]{3}{*}{$\begin{array}{l}\text { Clip } \\
\text { (monthly) }\end{array}$} & 6 CEMA;0 PSSP & $\begin{array}{l}\text { Stem } \\
\text { Root } \\
\text { Crown }\end{array}$ & $\begin{array}{r}6.8(0.9) \\
14.5(4.0) \\
13.6(3.9)\end{array}$ & $\begin{array}{l}3.1(0.7) \\
4.6(2.2) \\
3.1(1.2)\end{array}$ \\
\hline & 4 CEMA;2 PSSP & $\begin{array}{l}\text { Stem } \\
\text { Root } \\
\text { Crown }\end{array}$ & $\begin{array}{l}6.6(0.5) \\
25.4- \\
15.1-\end{array}$ & $\begin{array}{l}3.2(0.3) \\
7.1- \\
2.7-\end{array}$ \\
\hline & 2 CEMA;4 PSSP & $\begin{array}{l}\text { Stem } \\
\text { Root } \\
\text { Crown }\end{array}$ & $\begin{array}{l}6.8(0.5) \\
8.4- \\
-\end{array}$ & $\begin{array}{l}4.4(0.8) \\
3.6- \\
-\end{array}$ \\
\hline
\end{tabular}

'Numbers in parentheses are standard errors, no standard error is presented when insufficient plant material made it impossible to analyze TNC.

The relationship of pool TNC and TNC on a percentage basis was high with correlation coefficients of $0.91,0.85$ and 0.96 for stems, roots and crowns, respectively. However, pools within the control plants were reduced from $50-80 \%$ with monthly defoliations. The corresponding reductions in concentrations were about $50 \%$ (Table 2). Since "pools" data reflect the small, residual biomass, they probably provide a better indication of energy reserves. The correlation coefficients also indicate that at the termination of our study, the 2 methods of expressing carbohydrate reserves were equally reliable for spotted knapweed stems and crowns. They were not similar for roots. The relationship between the 2 methods at other stages of growth is unknown.

\section{Implications}

We found that frequent defoliations of knapweed reduced carbohydrate concentrations and pools. Our results are similar to Donart (1969) who found that root reserves of senecio (Senecio integerrimus Nutt.) and geranium (Geranium fremontii Torr.) are reduced following spring defoliation. Although longevity of rangeland forbs has not been evaluated in terms of carbohydrate reserves, the importance of reserves to alfalfa survival has been documented (Boyce and Volenec 1992). Since evidence indicating that spotted knapweed responds dif- 
ferently than alfalfa to environmental stress is lacking, it is logical to hypothesize that knapweed survival may also be adversely affected by frequent defoliation and subsequent reduction in total nonstructural carbohydrates. However, a species success in a community is not only related to defoliation and TNC, but is also influenced by differential use of resources, meristematic activity, differential defoliation levels, pathogens and other natural enemies, and reproductive strategies (Branson 1956, Caldwell et al. 1981, Caldwell 1984, and Richards and Caldwell 1985).

Because knapweed presently is a large component of many plant communities, it is conjectured that one or more of the above factors compensate for the adverse impact of defoliation and lower total nonstructural carbohydrates on an individual plant, and contribute to knapweed's success at the community level. Therefore, we are not optimistic about the use of traditional livestock grazing to significantly reduce spotted knapweed populations in native bunchgrass communities.

\section{Literature Cited}

Bedunah, D.J. 1992. The complex ecology of weeds, grazing and wildlife. Western Wildlands, 18:6-11.

Boyce, P.J., and J.J. Volenec. 1992. Taproot carbohydrate concentrations and stress tolerance of contrasting alfalfa genotypes. Crop Sci. 32:757-761.

Branson, F.A. 1956. Quantitative effects of clipping treatments on five range grasses. J. Range Manage. 9:86-88.

Caldwell, M.M. 1984. Plant requirements for prudent grazing, p. 117-152. In Developing strategies for Rangeland Management. A report prepared by the committee on developing strategies for rangeland management. National Research Council/National Academy of Sciences.

Caldwell, M.M., J.H. Richards, D.A. Johnson, R.S. Nowak, and R.S. Dzurec. 1981. Coping with herbivory: photosynthetic capacity and resource allocation in two semiarid Agropyron bunchgrasses. Oecologia 50:14-24.

Donart, G.B. 1969. Carbohydrate reserves of six mountain plants as related to growth. J. Range Manage. 22:411-415.

Donart, G.B., and C.W. Cook. 1970. Carbohydrate reserve content of mountain range plants following defoliation and regrowth. J. Range Mange. 23:15-19.

Kelsey, R.G., and R.D. Mihalovich. 1987. Nutrient composition of spotted knapweed (Centaurea maculosa). J. Range Manage. 40:277-281.
Kennett, G.A., J.R. Lacey, C.A. Butt, K.M. Olson-Rutz, and M.R. Haferkamp. 1992. Effects of defoliation, shading and competition on spotted knapweed and bluebunch wheatgrass. J. Range Manage. 45:363-369.

Lacey, C.A., J.R. Lacey, P.K. Fay, J.M. Story and D.L. Zamora. 1992. Controlling knapweed on Montana rangeland. Montana State Univ. Extension Service Circ. 311.

Lacey, J.R., and B.E. Olson. 1991. Environmental and economic impacts of noxious range weeds, p. 5-16. In: L.F. James, J.D. Evans, M.H. Ralphs, and R.D. Child (eds.), Noxious Range Weeds. Westview Press, Inc. Boulder, $\mathrm{CO}$.

Lym, R.G., and C.G. Messersmith. 1987. Carbohydrates in leafy spurge roots as influenced by environment. J. Range Mange. 40:139-144.

Menke, J.W., and M.J. Trlica. 1981. Carbohydrate reserve, phenology, and growth cycles of nine Colorado range species. J. Range Manage. 34:269277.

Reynolds, J. H. 1971. Carbohydrate trends in alfalfa (Medicago sativa L.) roots under several forage harvest schedules. Crop Sci. 11:103-106.

Richards, J.H., and M.M. Caldwell. 1985. Soluble carbohydrates, concurrent photosynthesis and efficiency in regrowth following defoliation: a field study with Agropyron species. J. of Applied Ecol. 22:907-920.

Robbins, J. 1990. Grazing knapweed using holistic resource management. In: Proc. Range Weeds-1989 Pacific Northwest Range Management Short Course, January 24-26, 1989. Spokane Wash. Washington State Univ. Coop. Ext., Pullman, Wash.

Roché, B.F., Jr., G.L. Piper, and C.J. Talbott. 1986. Knapweeds of Washington. Coop. Ext. Coll. of Agr. and Home Econ., Washington State Univ. EB 1393, Pullman, Wash.

Roché, B.F., Jr., and C.J. Talbott. 1986. The collection history of Centaureas found in Washington State. Agr.. Res. Cent., Wash. State Univ. Res. Bull. XB 0978, Pullman, Wash.

SAS. 1988. SAS users guide: Statistics. SAS Institute Inc. Cary, N.C.

Smith, D., G.M. Paulsen, and C.A. Raguse. 1964. Extraction of total available carbohydrates from grass and legume tissue. Plant Physiol. 39:960962.

Trlica, M.J., Jr., and C.W. Cook, 1971. Defoliation effects on carbohydrate reserves of desert species. J. Range Manage. 24:418-424.

Tyser, R.W., and C.H. Key. 1988. Spotted knapweed in natural area fescue grasslands: an ecological assessment. Northwest Sci. 62:981-987.

Watson, A.K., and A.J. Renney. 1974. The biology of canadian weeds. Centaurea diffusa and $C$. maculosa. Can. J. Plant Sci. 54:687-701. 